\title{
Effects of grazing on carbon and nitrogen in plants and soils in a semiarid desert grassland, China
}

\author{
Hui AN*, GuoQi LI \\ Ministry of Education Key Laboratory for Restoration and Reconstruction of Degraded Ecosystem in Northwestern China, United Center \\ for Ecology Research and Bioresource Exploitation in Western China, Ningxia University, Yinchuan 750021, China
}

\begin{abstract}
Grazing can modulate the feedback between vegetation and soil nutrient dynamics (carbon and nitrogen), altering the cycles of these elements in grassland ecosystems. For clarifying the impact of grazing on the $\mathrm{C}$ and $\mathrm{N}$ in plants and soils in the desert grassland of Ningxia, China, we examined the plant biomass, SOC (soil organic carbon), total soil $\mathrm{N}$ and stable isotope signatures of plants and soils from both the grazed and ungrazed sites. Significantly lower aboveground biomass, root biomass, litter biomass and vegetation coverage were found in the grazed site compared to the ungrazed site, with decreases of $42.0 \%, 16.2 \%, 59.4 \%$ and $30.0 \%$, respectively. The effects of grazing on plant carbon, nitrogen, $\delta^{15} \mathrm{~N}$ and $\delta^{13} \mathrm{C}$ values were uniform among species. The levels of plant carbon and nitrogen in grasses were greater than those in the forbs (except for the carbon of Cynanchum komarovii and Euphorbia esula). Root ${ }^{15} \mathrm{~N}$ and ${ }^{13} \mathrm{C}$ values increased with grazing, while the responses of root carbon and nitrogen to grazing showed no consistent patterns. Root ${ }^{15} \mathrm{~N}$ and ${ }^{13} \mathrm{C}$ were increased by $79.0 \%$ and $22.4 \%$ in the grazed site compared to the ungrazed site, respectively. The values of SOC and total $\mathrm{N}$ were significantly lower in the grazed than in the ungrazed sites for all sampling depths $(0-10$ and 10-20 cm), and values of SOC and total N at the surface $(0-10 \mathrm{~cm})$ were lower than those in the deeper soils $(10-20 \mathrm{~cm})$. Soil $\delta^{15} \mathrm{~N}$ values were not affected by grazing at any sampling depth, whereas soil $\delta^{13} \mathrm{C}$ values were significantly affected by grazing and increased by $19.3 \%$ and $8.6 \%$ in the soils at $0-10$ and $10-20 \mathrm{~cm}$, respectively. The soil $\delta^{13} \mathrm{C}$ values $(-8.3 \%$ o to $-6.7 \%$ ) were higher than those for roots $(-20.2 \%$ o to $-15.6 \%$ ) and plant tissues $(-27.9 \%$ o to $-13.3 \%$ ). Our study suggests that grazing could greatly affect soil organic carbon and nitrogen in contrast to ungrazed grassland and that grazing appears to exert a negative effect on soil carbon and nitrogen in desert grassland.
\end{abstract}

Keywords: grazing; ${ }^{15} \mathrm{~N} ;{ }^{13} \mathrm{C}$; soil properties; desert grassland; plant properties

Citation: Hui AN, GuoQi LI. 2015. Effects of grazing on carbon and nitrogen in plants and soils in a semiarid desert grassland, China. Journal of Arid Land, 7(3): 341-349. doi: 10.1007/s40333-014-0049-x

Grasslands are an important component of the global carbon cycle, covering approximately $25.4 \%$ of the total land area and storing greater than $10 \%$ of the terrestrial biomass of $\mathrm{C}$ and $10 \%$ to $30 \%$ of the global soil organic carbon (SOC) (Schlesinger, 1997; Scurlock and Hall, 1998). Changes in C storage in grassland ecosystems have the potential to modify the global C cycle and indirectly influence climate change (Conant et al., 2001). Grassland ecosystems can influence global environmental change through the strong potential for carbon and nitrogen sequestration. Hu- man activity has adversely affected global $\mathrm{C}$ and $\mathrm{N}$ cycles and has contributed to an alteration in climate that will generate discernible feedbacks to all organisms and ecosystems.

Grazing by domestic livestock is one of the major human activities in semiarid grasslands around the world (Gillson and Hoffman, 2007). Grazing modifies the $\mathrm{C}$ and $\mathrm{N}$ cycles, which may change $\mathrm{C}$ and $\mathrm{N}$ accumulation in the soil (Piñeiro et al., 2006). Grazing may simultaneously increase $\mathrm{N}$ availability and $\mathrm{N}$ conservation by stimulating $\mathrm{N}$ mineralization and reducing

\footnotetext{
*Corresponding author: Hui AN (E-mail: anhui81@gmail.com) Received 2014-05-19; revised 2014-11-03; accepted 2014-11-25

(C) Xinjiang Institute of Ecology and Geography, Chinese Academy of Sciences, Science Press and Springer-Verlag Berlin Heidelberg 2015
} 
$\mathrm{N}$ losses (Frank et al., 2000). Nitrogen mineralization is stimulated by grazing primarily because of the deposition of readily decomposable feces that are rich in nitrogen (Tracy and Frank, 1998). Grazing can impose a direct effect on $\mathrm{N}$ cycling by the grazer, removing plant tissues (Van Wijnen et al., 1999), trampling plants (Zacheis et al., 2002) and depositing readily decomposable feces that are rich in nitrogen (Rossignol et al., 2006). Additionally, grazing can exhibit an indirect effect by altering plant species composition (Olofsson et al., 2001), by causing changes in nitrogen content of plant tissues (Baron et al., 2002) and by affecting plant litter decomposition or soil microbial activities (Stark and Grellmann, 2002). Inconsistent responses of SOC to grazing for grassland have been reported. This is the SOC showed positive, negative or no response to grazing (Cui et al., 2005; Derner et al., 2006; Golluscio et al., 2009; Wu et al., 2010). The use of a natural abundance of stable carbon and nitrogen isotopes $\left(\delta^{13} \mathrm{C}\right.$ and $\left.\delta^{15} \mathrm{~N}\right)$ has proven particularly useful for interpreting the cycling of $\mathrm{C}$ and $\mathrm{N}$ (Ehleringer et al., 2000; Templer et al., 2007). Soil $\delta^{13} \mathrm{C}$ is primarily related to plant-derived organic $\mathrm{C}$ and the photosynthetic pathways of the plant (Dixon et al., 2010). The $\delta^{15} \mathrm{~N}$ of plants and soils is a function of the internal $\mathrm{N}$ transformation that occurs in the plant-soil system (Nadelhoffer and Fry, 1994). Variability in plant and soil ${ }^{15} \mathrm{~N}\left(\delta^{15} \mathrm{~N}\right)$ derives primarily from the physiological and biogeochemical processes in the $\mathrm{N}$ cycle. The natural abundance of $\delta^{15} \mathrm{~N}$ is regulated not only by internal $\mathrm{N}$ cycling via mineralization, nitrification, denitrification, leaching, gaseous losses $\left(\mathrm{NH}_{3}\right.$ volatilization and $\mathrm{N}_{2} \mathrm{O}$ emission) and inputs but also by extrinsic factors, such as fertilization (Frank et al., 2004), climate (Cheng et al., 2009) and grazing (Frank et al., 2000). Grazing may regulate $\mathrm{N}$ cycling rates by redistributing $\mathrm{N}$ within systems, and consequently, it shows a variety of impacts on $\delta^{15} \mathrm{~N}$ in plant-soil systems. The effects of grazing intensity on ecosystem ${ }^{15} \mathrm{~N}$ are often controversial, showing either an increase (Frank et al., 2000; Frank et al., 2004) or a decrease (Golluscio et al., 2009) in ${ }^{15} \mathrm{~N}$ values. However, increased mineralization and losses via $\mathrm{NH}_{3}$ volatilization in urine indicate that the enrichment of soil ${ }^{15} \mathrm{~N}$ could occur with increased grazing intensity (Frank and Evans, 1997). A positive correlation of topsoil ${ }^{15} \mathrm{~N}$ with $\mathrm{NH}_{3}$ volatilization, net nitrification and denitrification, and ${ }^{15} \mathrm{~N}$ of topsoil might be used as an indicator of $\mathrm{N}$ cycling rates concerning gaseous $\mathrm{N}$ losses via $\mathrm{NH}_{3}$ volatilization and $\mathrm{N}_{2} \mathrm{O}$ emission $(\mathrm{Wu}$ et al., 2010).

Grasslands are the dominant landscape in China and account for nearly $40 \%$ of the national land area, and $78 \%$ of the grassland in China is located in the northern temperate zone (Kang et al., 2007). These grasslands are faced with severe degradation and desertification due to rapid population growth coupled with poor grassland management (e.g. overgrazing). Understanding the effects of grazing on grassland productivity and $\mathrm{C}$ and $\mathrm{N}$ cycling in desert grassland is crucial for the rational utilization of the grasslands. This paper focuses on a comparison of vegetation biomass, coverage, carbon and nitrogen in a grazed with an ungrazed sites to address whether long-term grazing reduces grassland productivity and stimulates nutrient cycling, thereby resulting in reduced $\mathrm{C}$ and $\mathrm{N}$ in desert grassland. Our observations will be important to a better understanding of the effects of grazing.

\section{Materials and methods}

\subsection{Study area}

The experiment was conducted in the desert grassland in Yanchi county $\left(37^{\circ} 57^{\prime} \mathrm{N}, 107^{\circ} 00^{\prime} \mathrm{E} ; 1,430 \mathrm{~m}\right.$ asl), Ningxia Hui autonomous region, China. This area has a temperate continental semiarid monsoonal climate. The annual mean temperature is $7.5^{\circ} \mathrm{C}$, with a monthly minimum of $-8.7^{\circ} \mathrm{C}$ in January to the maximum of $22.4^{\circ} \mathrm{C}$ in July, and has approximately 165 days of frost. The mean annual precipitation is $280 \mathrm{~mm}$, over $70 \%$ of which occurs between June and September. The mean annual potential pan evaporation was approximately $2,710 \mathrm{~mm}$, about ten times greater than the annual precipitation. The zonal soils are loessial and light sierozem, and the azonal soils are sandy arenosol, alkaline saline and meadow soil, all poor in fertility with loose structure and very susceptible to wind erosion (Zhang et al., 2004). The zonal vegetation is typical desert grassland, dominated by $A r$ temisia desertorum, Leymus secalinus, Agropyron mongolicum, Stipa breviflora, Glycyrrhiza uralensis, Cynanchum komarovii, Potentilla bifurca, Caragana 
tibetica, Oxytropis aciphylla, Oxytropis racemosa, Salsola sinkiangensis, Artemisia capillaries and $\mathrm{Ka}$ lidium foliatum.

\subsection{Experimental design}

The grazing experiment was carried out at a grassland monitoring station, which was established in 2004. This grassland was under free-range grazing by sheep, with grazing occurring mainly from April to October. The theoretical livestock carrying capacity of desert steppe in this region should be less than 0.75 sheep $/ \mathrm{hm}^{2}$ (Ma and Xie, 2008). We selected two grazing treatments: ungrazed and grazed $\left(1.0 \mathrm{sheep} / \mathrm{hm}^{2}\right)$. Each experimental treatment included three replicate plots, giving a total of six plots for the experiment. For the grazed plots, with an estimated $54 \%$ of aboveground biomass consumed by sheep each year, the vegetation coverage ranged from $46 \%$ to $57 \%$. Ungrazed plots had been fenced since 2004 to prevent grazing by large animals. The grazed plots $\left(6.1-8.0 \mathrm{hm}^{2}\right)$ are relatively large compared to the ungrazed plots $\left(4.9-5.8 \mathrm{hm}^{2}\right)$. In each plot, 15 sampling quadrats $(1 \mathrm{~m} \times 1 \mathrm{~m})$ were randomly selected with the constraint that the chosen quadrats be at least $0.5 \mathrm{~m}$ from the margin to avoid any edge effects.

\subsection{Sampling of aboveground biomass and domi- nant species}

Aboveground biomass and vegetation coverage were sampled in mid-August of 2011 at each sampling site. Within each quadrat, litter (herbage produced in previous years) was removed from the quadrats by hand-raking and was then retained. Fine, fragmented and partially decomposed litter (humus) lying on the soil surface was not included because it was mixed with mineral soil and could not be separated. All living biomass was harvested at the ground level, and the residual standing litter was hand sorted and added to the raked litter. All biomass was dried at $70^{\circ} \mathrm{C}$ for $48 \mathrm{~h}$ to a constant mass and then weighed. After drying, the same species from five quadrats were combined, which created three replications for each plot in the grazed and the ungrazed sites. Thirteen dominant species (Table 1) were analyzed for carbon, total nitrogen contents and $\delta^{15} \mathrm{~N}$ and $\delta^{13} \mathrm{C}$ values. When the material of plant samples obtained by using the quadrat method was insufficient for nutrient and isotopic analysis, additional samples were obtained from each grazing treatment outside the quadrat.

Table 1 Effects of grazing on carbon and nitrogen content, $\mathrm{C}$ and $\mathrm{N}$ isotope ratios of plants in desert grassland

\begin{tabular}{|c|c|c|c|c|c|c|c|c|c|}
\hline \multirow{2}{*}{ Plant species } & \multirow{2}{*}{ Type } & \multicolumn{2}{|c|}{ Total nitrogen $(\mathrm{mg} / \mathrm{g})$} & \multicolumn{2}{|c|}{ Carbon content $(\mathrm{mg} / \mathrm{g})$} & \multicolumn{2}{|c|}{$\delta^{15} \mathrm{~N}(\%)$} & \multicolumn{2}{|c|}{$\delta^{13} \mathrm{C}(\%)$} \\
\hline & & Grazed & Ungrazed & Grazed & Ungrazed & Grazed & Ungrazed & Grazed & Ungrazed \\
\hline Stipa breviflora & G & $23.0^{\mathrm{a}}$ & $21.9^{\mathrm{a}}$ & $431.3^{\mathrm{b}}$ & $462.9^{\mathrm{a}}$ & $0.80^{\mathrm{a}}$ & $0.66^{\mathrm{a}}$ & $-26.7^{\mathrm{a}}$ & $-26.6^{\mathrm{a}}$ \\
\hline Agropyron mongolicum & $\mathrm{G}$ & $15.8^{\mathrm{a}}$ & $18.3^{\mathrm{a}}$ & $412 .{ }^{8 b}$ & $439.7^{\mathrm{a}}$ & $1.11^{\mathrm{a}}$ & $0.29^{\mathrm{b}}$ & $-26.9^{\mathrm{b}}$ & $-25.8^{\mathrm{a}}$ \\
\hline Pennisetum flaccidum & G & $32.6^{\mathrm{a}}$ & $26.2^{\mathrm{a}}$ & $392.8^{\mathrm{a}}$ & $381.6^{\mathrm{a}}$ & $0.35^{\mathrm{b}}$ & $0.67^{\mathrm{a}}$ & $-13.3^{\mathrm{a}}$ & $-14.3^{\mathrm{b}}$ \\
\hline Glycyrrhiza uralensis & $\mathrm{L}$ & $19.1^{\mathrm{a}}$ & $21.5^{\mathrm{a}}$ & $402.9^{\mathrm{a}}$ & $410.0^{\mathrm{a}}$ & $0.53^{\mathrm{b}}$ & $1.08^{\mathrm{a}}$ & $-26.0^{\mathrm{a}}$ & $-25.1^{\mathrm{a}}$ \\
\hline Lespedeza potaninii & $\mathrm{L}$ & $23.0^{\mathrm{a}}$ & $21.4^{\mathrm{a}}$ & $380.8^{\mathrm{a}}$ & $418.7^{\mathrm{a}}$ & $-1.70^{\mathrm{b}}$ & $-0.97^{\mathrm{a}}$ & $-27.1^{\mathrm{b}}$ & $-25.8^{\mathrm{a}}$ \\
\hline Cynanchum komarovii & $\mathrm{F}$ & $17.6^{\mathrm{b}}$ & $22.5^{\mathrm{a}}$ & $440.7^{\mathrm{a}}$ & $450.2^{\mathrm{a}}$ & $0.30^{\mathrm{a}}$ & $-0.38^{\mathrm{b}}$ & $-26.7^{\mathrm{a}}$ & $-26.3^{\mathrm{a}}$ \\
\hline Euphorbia esula & $\mathrm{F}$ & $22.5^{\mathrm{a}}$ & $21.5^{\mathrm{b}}$ & $387.9^{\mathrm{b}}$ & $423.7^{\mathrm{a}}$ & $0.51^{\mathrm{a}}$ & $-0.22^{\mathrm{b}}$ & $-25.5^{\mathrm{a}}$ & $-25.9^{\mathrm{b}}$ \\
\hline Peganum harmala & $\mathrm{F}$ & $19.7^{\mathrm{a}}$ & $16.6^{\mathrm{b}}$ & $379.6^{\mathrm{a}}$ & $346.4^{\mathrm{b}}$ & $5.42^{\mathrm{a}}$ & $5.36^{\mathrm{a}}$ & $-26.7^{\mathrm{a}}$ & $-26.6^{\mathrm{a}}$ \\
\hline Oxytropis aciphylla & $\mathrm{F}$ & $19.3^{\mathrm{a}}$ & $15.9^{\mathrm{a}}$ & $314.8^{\mathrm{a}}$ & $343.5^{\mathrm{a}}$ & $-0.92^{\mathrm{a}}$ & $-0.66^{\mathrm{a}}$ & $-26.8^{\mathrm{a}}$ & $-26.1^{\mathrm{a}}$ \\
\hline Oxytropis racemosa & $\mathrm{F}$ & $8.8^{\mathrm{a}}$ & $8.4^{\mathrm{a}}$ & $173.2^{\mathrm{a}}$ & $183.0^{\mathrm{a}}$ & $-0.52^{\mathrm{a}}$ & $-0.90^{\mathrm{b}}$ & $-26.8^{b}$ & $-26.4^{\mathrm{a}}$ \\
\hline Ixeridium graminifolium & $\mathrm{F}$ & $13.2^{\mathrm{a}}$ & $12.2^{\mathrm{a}}$ & $280.9^{\mathrm{a}}$ & $277.6^{\mathrm{a}}$ & $0.09^{\mathrm{a}}$ & $-1.28^{\mathrm{b}}$ & $-27.9^{b}$ & $-27.1^{\mathrm{a}}$ \\
\hline Corispermum hyssopifolium & $\mathrm{F}$ & $14.9^{\mathrm{a}}$ & $10.8^{\mathrm{a}}$ & $293.5^{\mathrm{a}}$ & $250.6^{\mathrm{a}}$ & $3.60^{\mathrm{a}}$ & $1.89^{\mathrm{b}}$ & $-27.0^{\mathrm{b}}$ & $-25.4^{\mathrm{a}}$ \\
\hline Salsola collina & $\mathrm{F}$ & $9.8^{\mathrm{b}}$ & $12.4^{\mathrm{a}}$ & $278.6^{\mathrm{a}}$ & $287.4^{\mathrm{a}}$ & $5.41^{\mathrm{a}}$ & $3.48^{\mathrm{a}}$ & $-14.1^{\mathrm{a}}$ & $-14.2^{\mathrm{a}}$ \\
\hline
\end{tabular}

Note: G, grass; L, legume; F, forb. Plant carbon content, nitrogen content, $\delta^{15} \mathrm{~N}$ and $\delta^{13} \mathrm{C}$ data in a row followed by different lowercase letters indicates significant difference at $P<0.05$ level.

\subsection{Sampling of soil and root biomass}

Soil samples were collected from 15 quadrats in each sampling plot in the grazed and ungrazed sites after the aboveground material was harvested. In each quadrat, soil was randomly collected from three points (3.8 $\mathrm{cm}$ in diameter) using a bucket auger and mixed 
into a single soil sample. The five samples from each plot were combined, which created three replications for each plot in the grazed and ungrazed treatments. The soil sampling depths were $0-10$ and $10-20 \mathrm{~cm}$. Meanwhile, a soil pit was dug to $30 \mathrm{~cm}$, and the root mass in a $20 \mathrm{~cm} \times 50 \mathrm{~cm}$ column was extracted to a depth of $0-30 \mathrm{~cm}$ to estimate the root biomass. The five root samples from each plot were combined, creating three replications for each plot. All soil samples were brought into the laboratory in airtight plastic bags. For the root biomass, the soil samples were rinsed in water to remove the soil and debris, and the root samples were then dried at $70^{\circ} \mathrm{C}$ for $48 \mathrm{~h}$ and weighed. All of the soil samples were air-dried and then filtered through a $2 \mathrm{~mm}$ sieve, and the visible roots and plant debris were discarded.

\subsection{Isotopic and elemental analyses}

The aboveground plant tissue, root and soil samples were ground into fine powders with a mortar and pestle. The $\mathrm{C}$ of the aboveground plant tissue, root and soil was determined by the $\mathrm{K}_{2} \mathrm{Cr}_{2} \mathrm{O}_{7}-\mathrm{H}_{2} \mathrm{SO}_{4}$ solution digestion method with the oil-bath heating, and the nitrogen $(\mathrm{N})$ of the aboveground plant tissue, root and soil was analyzed using a Kjeltec analyzer (Kjeltec 2300 Analyzer Unit, Foss, Sweden). The $\delta^{15} \mathrm{~N}$ and $\delta^{13} \mathrm{C}$ values of the aboveground plant tissue, root and soil were determined by an isotope ratio mass spectrometer (Delta V advantage, Thermo Fisher Scientific, Inc., USA) coupled with an elemental analyzer (Flash EA 1112 HT, Thermo Fisher Scientific, Inc., USA). The carbon and total nitrogen contents of the aboveground plant tissue, root and soil were presented according to mass basis $(\mathrm{mg} / \mathrm{g})$.

\subsection{Data analysis}

Statistical analyses were performed using SPSS 15.0 software (SPSS for Windows, Chicago, IL, USA). The statistical comparisons of the mean values were conducted using the independent samples t-test for vegetation coverage, aboveground biomass, litter biomass, and root biomass, root/shoot ( $\mathrm{R} / \mathrm{S}$ ratio), aboveground plant tissue, root carbon properties, root nitrogen properties between the grazed and ungrazed treatments. The effects of grazing and soil depth on soil properties were analyzed with ANOVA. Significant differences for all statistical tests were evaluated at the level of $P<0.05$.

\section{Results}

\subsection{Plant biomass and vegetation coverage resp- onse to grazing}

Grazing significantly decreased aboveground biomass $(F=1.499, P<0.01)$, litter biomass $(F=0.009, P<0.05)$, root biomass $(F=0.017, P<0.01)$ and vegetation coverage $(F=0.047, P<0.01)$ (Fig. 1) but significantly increased the root/shoot ratio $(F=0.156, P<0.01)$. The aboveground biomass, litter biomass, root biomass and vegetation coverage decreased by $42.0 \%, 59.4 \%$, $16.2 \%$ and $30.0 \%$, respectively, in the grazed compared to the ungrazed treatments.

\subsection{Effects of grazing on plant carbon, nitrogen, $\delta^{15} \mathrm{~N}$ and $\delta^{13} \mathrm{C}$ values}

Among the 13 dominant species analyzed in the grazed and ungrazed desert grasslands, the nitrogen content increased with grazing for nine species $(S$. breviflora, P. flaccidum, L. potaninii, E. esula, P. harmala, O. aciphylla, O. racemosa, I. graminifolium and $C$. hyssopifolium) and decreased with grazing for four species (A. mongolicum, G. uralensis, C. komarovii and S. collina) (Table 1). Grazing significantly increased the nitrogen content of $E$. esula and $P$. harmala and significantly decreased the nitrogen content of $C$. komarovii and $S$. collina. The nitrogen contents of the forbs and legumes were lower than those of the grasses (the only exception being A. mongolicum).

Among the 13 dominant species, grazing increased the plant carbon contents for four species (P.flaccidum, $P$. harmala, I. graminifolium and C. hyssopifolium) and decreased the plant carbon contents for nine species $(S$. breviflora, A. mongolicum, G. uralensis, L. potaninii, $C$. komarovii, E. esula, O. aciphylla, O. racemosa and $S$. collina). Grazing significantly increased the carbon content of $P$. harmala and significantly decreased the carbon contents of $S$. breviflora, A. mongolicum and $E$. esula. The plant carbon contents of the grasses and legumes were greater than those of the forbs (except for C. komarovii and E. esula).

The natural abundance of ${ }^{15} \mathrm{~N}$ in forb plant tissues increased by grazing (the only exception being $O$. aciphylla; Table 1). The $\delta^{15} \mathrm{~N}$ values for the forbs species ranged from $-0.92 \%$ to $5.42 \%$ on the grazed site and were lower, ranging from $-1.28 \%$ to $5.36 \%$, 

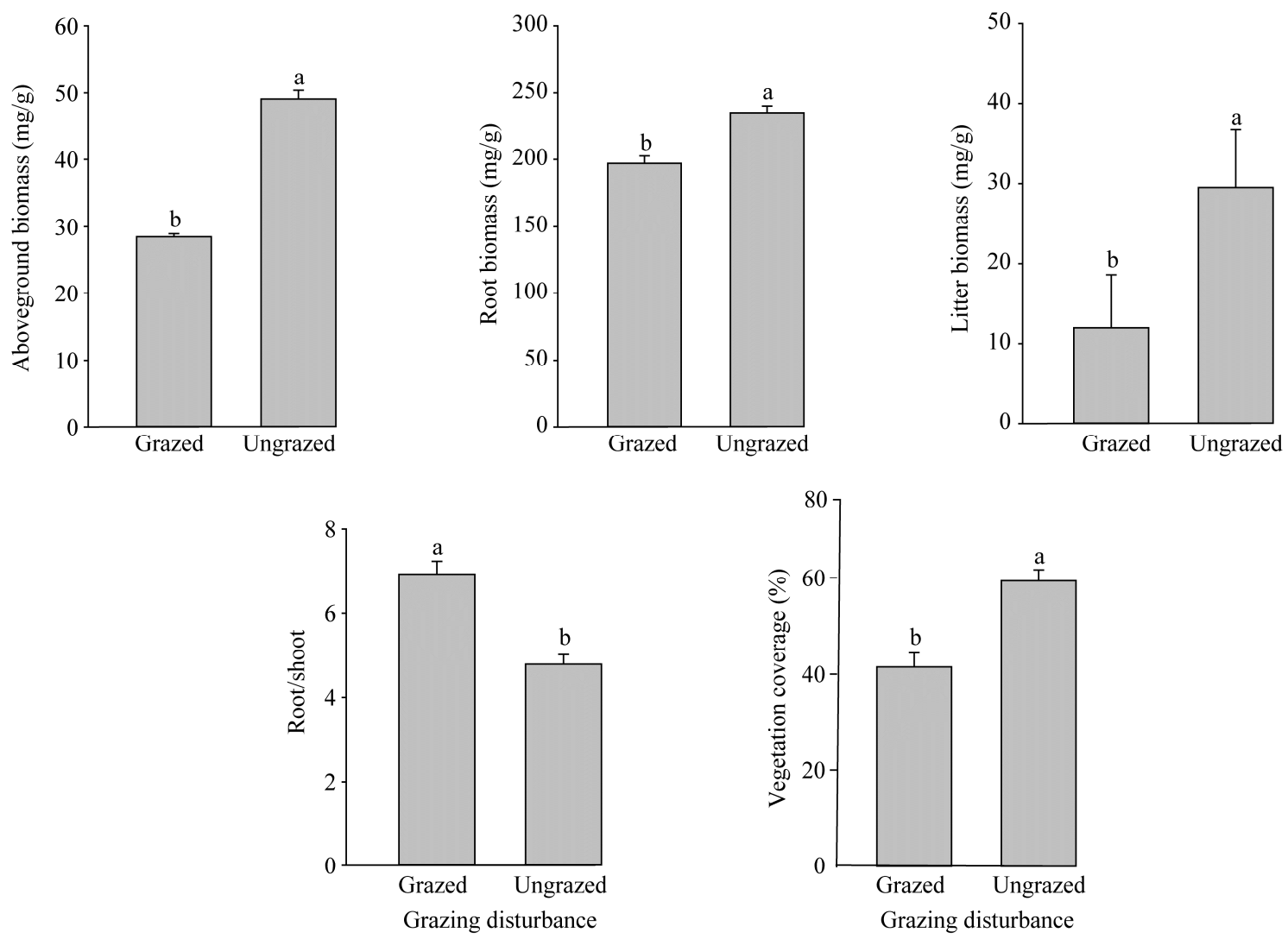

Fig. 1 Effects of grazing on plant biomass and vegetation coverage in desert grassland. Different letters represent significant differences between ungrazed and grazed treatments at $P<0.05$ level.

on the ungrazed site. Grazing significantly decreased the $\delta^{15} \mathrm{~N}$ values of the legume species, and the $\delta^{15} \mathrm{~N}$ values were lowest for $L$. potaninii in the grazed site. The effects of grazing on $\delta^{15} \mathrm{~N}$ values of grasses species were uniform among species. The $\delta^{15} \mathrm{~N}$ values of $P$. flaccidum decreased significantly and those of $A$. mongolicum increased significantly with grazing.

Eleven species in our study used the $\mathrm{C}_{3}$ photosynthetic pathway; therefore, discrimination against ${ }^{13} \mathrm{C}$ in the atmospheric $\mathrm{CO}_{2}$ was similar, and the $\delta^{13} \mathrm{C}$ values fell within a narrow range from $-27.9 \%$ to $-25.1 \%$ (Table 1). The $\delta^{13} \mathrm{C}$ values of two $\mathrm{C}_{4}$ species ranged from $-14.3 \%$ to $-13.3 \%$. Grazing decreased the $\delta^{13} \mathrm{C}$ values of legumes and grasses species (the only exception being P. flaccidum), and the $\delta^{13} \mathrm{C}$ for $A$. mongolicum and $L$. potaninii changed significantly with grazing, though the differences were small, ranging from $1.1 \%$ to $1.3 \%$. The effects of grazing on the $\delta^{13} \mathrm{C}$ values of the forb species were uniform among species. Grazing did not affect the $\delta^{13} \mathrm{C}$ values for C. komarovii, P. harmala, O. aciphylla and S. collina and decreased or increased significantly for E. esula, I. graminifolium, O. racemosa and C. hyssopifolium.

Grazing did not affect the carbon and nitrogen contents of the roots (Table 2). A lower nitrogen content, but greater carbon content, was found in the grazed site than in the ungrazed site. Grazing significantly increased root ${ }^{15} \mathrm{~N} \quad(F=0.154, \quad P<0.01)$ and ${ }^{13} \mathrm{C}$ $(F=1.069, P<0.01)$ values, and the root ${ }^{15} \mathrm{~N}$ and ${ }^{13} \mathrm{C}$ values were increased by $79.0 \%$ and $22.4 \%$, respectively.

\subsection{Effects of grazing on SOC, total $\mathrm{N},{ }^{15} \mathrm{~N}$ and $\delta^{13} \mathrm{C}$ values}

The grazing and the soil depth affected SOC $(P<0.05)$. The SOC were higher in the ungrazed site ( 2.47 and $3.41 \mathrm{mg} / \mathrm{g}$ for $0-10$ and $10-20 \mathrm{~cm}$ soils, respectively) than the grazed site $(2.11$ and $3.01 \mathrm{mg} / \mathrm{g}$, respectively) (Table 3). For the grazed and ungrazed treatments, the SOC content in the surface $(0-10 \mathrm{~cm})$ was lower than that in the $10-20 \mathrm{~cm}$ soil. The $\delta^{13} \mathrm{C}$ values for the $\mathrm{SOC}$ ranged from $-8.3 \%$ to $-6.7 \%$ and were significantly affected by the grazing (Table 3 ). 
Table 2 Effects of grazing on carbon and nitrogen contents, C and $\mathrm{N}$ isotope values of roots in desert grassland

\begin{tabular}{ccccc}
\hline Treatment & $\begin{array}{c}\text { Total nitrogen } \\
(\mathrm{mg} / \mathrm{g})\end{array}$ & $\begin{array}{c}\text { Carbon content } \\
(\mathrm{mg} / \mathrm{g})\end{array}$ & $\begin{array}{c}\delta^{15} \mathrm{~N} \\
(\% \mathrm{o})\end{array}$ & $\begin{array}{c}\delta^{13} \mathrm{C} \\
(\% \mathrm{o})\end{array}$ \\
\hline Grazed & $9.23^{\mathrm{a}}$ & $304.47^{\mathrm{a}}$ & $0.52^{\mathrm{a}}$ & $-15.6^{\mathrm{a}}$ \\
Ungrazed & $10.23^{\mathrm{a}}$ & $291.40^{\mathrm{a}}$ & $0.29^{\mathrm{b}}$ & $-20.2^{\mathrm{b}}$
\end{tabular}

Note: The carbon content, nitrogen content, $\delta^{15} \mathrm{~N}$ and $\delta^{13} \mathrm{C}$ of root in a column followed by different lower case letters indicates significant difference at $P<0.05$ level.

Table 3 Effect of grazing on soil properties in desert grassland

\begin{tabular}{cccr}
\hline \multirow{2}{*}{ Soil property } & $\begin{array}{c}\text { Soil depth } \\
(\mathrm{cm})\end{array}$ & \multicolumn{2}{c}{ Treatment } \\
\cline { 3 - 4 } & $0-10$ & $0.25^{\mathrm{bB}}$ & $0.33^{\mathrm{aB}}$ \\
\hline \multirow{2}{*}{$\mathrm{TN}(\mathrm{mg} / \mathrm{g})$} & $10-20$ & $0.37^{\mathrm{bA}}$ & $0.47^{\mathrm{aA}}$ \\
& $0-10$ & $2.11^{\mathrm{bB}}$ & $2.47^{\mathrm{aB}}$ \\
SOC $(\mathrm{mg} / \mathrm{g})$ & $10-20$ & $3.01^{\mathrm{bA}}$ & $3.41^{\mathrm{aA}}$ \\
& $0-10$ & $4.76^{\mathrm{aB}}$ & $4.63^{\mathrm{aB}}$ \\
$\delta^{15} \mathrm{~N}(\%)$ & $10-20$ & $5.04^{\mathrm{aA}}$ & $5.06^{\mathrm{aA}}$ \\
& $0-10$ & $-6.70^{\mathrm{aA}}$ & $-8.30^{\mathrm{bA}}$ \\
$\delta^{13} \mathrm{C}(\%)$ & $10-20$ & $-7.40^{\mathrm{aA}}$ & $-8.10^{\mathrm{bA}}$ \\
\hline
\end{tabular}

$\overline{\text { Note: For each soil property, data in a row followed by different lowercase }}$ letters indicates significant grazing effect $(P<0.05)$ and data in a column followed by different uppercase letters indicate a significant depth effect $(P<0.05)$.

Similar effects of grazing and soil depth were also detected for soil total $\mathrm{N}$ (Table 3 ). The soil total $\mathrm{N}$ was higher in the ungrazed site $(0.33$ and $0.47 \mathrm{mg} / \mathrm{g}$ for the $0-10 \mathrm{~cm}$ and the $10-20 \mathrm{~cm}$ soil, respectively) than the grazed site $(0.25$ and $0.37 \mathrm{mg} / \mathrm{g})$. The soil total $\mathrm{N}$ followed trends similar to the SOC, with a lower total $\mathrm{N}$ in the surface soil. The $\delta^{15} \mathrm{~N}$ values for total soil $\mathrm{N}$ were more than 0 in all soil samples, indicating an enrichment of ${ }^{15} \mathrm{~N}$ relative to the standard atmospheric $\mathrm{N}_{2}$ $\left(\delta^{15} \mathrm{~N}=0 \%\right.$ ), the reference material for determining natural ${ }^{15} \mathrm{~N}$ abundance. Soil depth effects were detected for soil $\delta^{15} \mathrm{~N}$ values $(P<0.05)$, but grazing effects were not significant for $\delta^{15} \mathrm{~N}$ values. The $\delta^{15} \mathrm{~N}$ values for total $\mathrm{N}$ increased with soil depths from $+4.63 \%$ to $4.76 \%$ in the surface layer to $>+5 \%$ in the $10-20 \mathrm{~cm}$ soil layer.

\section{Discussion}

\subsection{Effect of grazing on productivity}

Plant productivity is an important metric of ecosystem functioning for desert grassland. The total aboveground biomass, root biomass, litter biomass and vegetation coverage of the ungrazed were higher than those in the grazed desert grassland. These results of changes in plant biomass and cover are consistent with those occurring at other grassland communities (Baron et al., 2002; Cheng et al., 2011; Zhou et al., 2011). This suggests that enclosure management may promote plant biomass and change the community structure and species. Grazing affects the root biomass by trampling and excretions and root biomass responses to livestock grazing are ambiguous (no change, increase or decrease) (Milchunas and Lauenroth, 1993; Gao et al., 2007; Cheng et al., 2011). Our results show that root biomass appears to be significantly decreased after long-term grazing on desert grassland. Heavy grazing may decrease productivity due to decreases in soil nutrient availability (Savadogo et al., 2007) and disruption of the structure of soil aggregates and surface crust by livestock trampling, which enhances soil organic matter decomposition and leads to the soil being susceptible to water and wind erosion (Neff et al., 2005). The increasing biomass allocation to the roots is an important adaptive response of plants to grazing. The root/shoot ratio significantly increased after long-term grazing. A high proportion of root biomass in the total biomass can enhance the capacity to tolerate environmental stresses and external disturbances.

\subsection{Effects of grazing on $\mathrm{C}$ and $\mathrm{N}$ of plant and soil}

Grazing alters $\mathrm{N}$ cycling in the grassland ecosystem, and such changes may constrain $\mathrm{C}$ accumulation in the soil (Piñeiro et al., 2006). The smaller SOC and total $\mathrm{N}$ under grazed compared to ungrazed grasslands are consistent with the findings of other researchers (Cui et al., 2005; Su et al., 2005), reflecting decreased inputs of both above- and below-ground vegetation and possibly accelerated decomposition of litter and soil organic matter. With grazing, plant growth was diminished and a larger proportion of this reduced production was removed by grazing; therefore, heavy grazing decreased both the aboveground litter deposition (Fig. 1) and the belowground carbon allocation. Grazing increased the aboveground plant tissue nitrogen of nine species, which is consistent with the results of Han et al. (2008) who reported that nitrogen of aboveground vegetation increased in response to grazing. The vegetation under grazing tends to consist mostly of young metabolic material because grazing precludes the accumulation of standing dead material.

Some studies have suggested that grazing could 
lead to an increase in $\delta^{15} \mathrm{~N}$ (Frank and Evans, 1997; Frank et al., 2004; Han et al., 2008), while a decrease or no apparent effect of grazing on $\delta^{15} \mathrm{~N}$ has also been reported (Golluscio et al., 2009). The increased $\delta^{15} \mathrm{~N}$ values of the $0-10 \mathrm{~cm}$ soil observed in the grazed compared to the ungrazed treatments suggests that grazing could have enriched soil $\delta^{15} \mathrm{~N}$ by affecting the isotopic composition of $\mathrm{N}$ input via dropping feces, trampling and the shift in the compositions of the plants and microbes (Frank and Evans, 1997). Grazing increased soil $\delta^{15} \mathrm{~N}$ by facilitating the processes that control $\mathrm{N}$ loss from the soil system, such as $\mathrm{NH}_{3}$ volatilization, denitrification and leaching. Because of the often limited water availability, $\mathrm{N}$ loss through leaching and denitrification is usually much less important than $\mathrm{N}$ loss through $\mathrm{NH}_{3}$ volatilization in arid and semiarid grassland. Grazing accelerates $\mathrm{N}$ loss by way of $\mathrm{NH}_{3}$ volatilization and other processes, especially in ecosystems with higher soil $\mathrm{pH}$ values (Frank and Evans, 1997; Frank et al., 2004). $\mathrm{NH}_{3}$ volatilization is a key mechanism responsible for the level of soil ${ }^{15} \mathrm{~N}$ enrichment in arid and semiarid grasslands. $\mathrm{NH}_{3}$ volatilization and/or denitrification of the surface soil cause the increase in ${ }^{15} \mathrm{~N}$ on urine patches. Grazer' urine and dung increased the soil ${ }^{15} \mathrm{~N}$ abundance, indicating that the grazer promoted $\mathrm{N}$ loss with those patches. The $\delta^{15} \mathrm{~N}$ values increasing with soil depths were consistent with the findings of other researches (Han et al., 2008; Cheng et al., 2009). The deeper soil layer tended to have significantly higher $\delta^{15} \mathrm{~N}$ values than the surface soil layer and can be explained by fractionation during decomposition and the ${ }^{15} \mathrm{~N}$-depleted $\mathrm{N}$ losses during microbial decomposition of organic matter in concert with the downward movement of residual substrate (Evans and Ehleringer, 1994). The input of ${ }^{15} \mathrm{~N}$-depleted foliar litter to the soil surface (Natelhoffer and Fry, 1988), the input of ${ }^{15} \mathrm{~N}$-depleted root litter and ${ }^{15} \mathrm{~N}$-enriched mycorrhizal fungi below the surface could result in deep soil horizons being substantially enriched in ${ }^{15} \mathrm{~N}$ relative to surface litter (Högberg et al., 1996). The partial conversion of nitrate during denitrification could strongly influence soil ${ }^{15} \mathrm{~N}$ values by creating a pool of ${ }^{15} \mathrm{~N}$-enriched nitrate that, subsequently, could be reassimilated by the microbial community and ultimately increase deep soil $\delta^{15} \mathrm{~N}$.

The effects of grazing on $\delta^{15} \mathrm{~N}$ values of plants were uniform among species. Isotopic fractionations during soil $\mathrm{N}$ transformation and plant $\mathrm{N}$ uptake could lead to observed differences in $\delta^{15} \mathrm{~N}$ values among plant species. Patterns of variation in ${ }^{15} \mathrm{~N}$ values among species indicate that plants acquire nitrogen in extremely nutrient-poor environments by competitive partitioning of the overall $\mathrm{N}$ pool. The natural abundance of ${ }^{15} \mathrm{~N}$ in the forb plant tissues increased with grazing, but $\delta^{15} \mathrm{~N}$ in legumes species decreased with grazing. A reduction in the $\delta^{15} \mathrm{~N}$ of legumes species that were grazed is consistent with Frank et al. (1997), as reported in Yellowstone, USA. The higher rates of net $\mathrm{N}$ ammonification caused by grazing may increase nitrification rates and the availability of $\mathrm{NO}_{3}{ }^{-}$(Holland and Detling, 1990). Because nitrification discriminates against ${ }^{15} \mathrm{~N}, \mathrm{NO}_{3}{ }^{-}$should be isotopically lighter than $\mathrm{NH}_{4}{ }^{+}$(Feigin et al., 1974). Grazing depleted plant ${ }^{15} \mathrm{~N}$ values were, in part, the result of plants assimilating proportionally more $\mathrm{NO}_{3}{ }^{-}$than $\mathrm{NH}_{4}{ }^{+}$in the Yellowstone grassland. Other than $\mathrm{NO}_{3}{ }^{-}, \mathrm{NH}_{4}{ }^{+}$uptake and the ratios of $\mathrm{NO}_{3}^{-}$to $\mathrm{NH}_{4}^{+}$uptake significantly affected the $\delta^{15} \mathrm{~N}$ of plants, with increasing $\mathrm{NH}_{4}{ }^{+}$uptake leading to decreased $\delta^{15} \mathrm{~N}$ values. We found that the plants in the desert grassland were depleted of ${ }^{15} \mathrm{~N}$ relative to the soil (except for $S$. collina and $P$. harmala), similar to other reports (Frank and Evans, 1997), although some exceptions exist. If discrimination occurs during the plant's uptake of $\mathrm{NH}_{4}{ }^{+}$and $\mathrm{NO}_{3}{ }^{-}$(Evans et al., 1996), the plant may become ${ }^{15} \mathrm{~N}$ depleted due to ${ }^{15} \mathrm{~N}$ discrimination during the ammonification and nitrification processes that yield isotopically light $\mathrm{NH}_{4}{ }^{+}$and $\mathrm{NO}_{3}{ }^{-}$relative to the soil organic N (Nadelhoffer and Fry, 1994). The significantly increased root $\delta^{15} \mathrm{~N}$ with grazing was consistent with the findings of Harris et al. (2007), who reported on the $\mathrm{N}$ content and the $\delta^{15} \mathrm{~N}$ of $P$. napostaense. The $\delta^{15} \mathrm{~N}$ of roots $(+0.29 \%$ to $0.52 \%$ ) was much lower than that for soil $\delta^{15} \mathrm{~N}(+4.63 \%$ to $5.06 \%$ ). The higher $\delta^{15} \mathrm{~N}$ in soil compared to root confirmed that the actively cycling $\mathrm{N}$ pool is most susceptible to biological transformation and that root uptake has a lower $\delta^{15} \mathrm{~N}$ compared to the soil (Han et al., 2008).

In contrast to other studies that did not show changes in soil $\delta^{13} \mathrm{C}$ with grazing, we found soil ${ }^{13} \mathrm{C}$ significant higher in grazed desert grassland. The soil 
$\delta^{13} \mathrm{C}$ values are related to changes in the isotopic signature of inputs or changes in the proportion of compounds of organic matter with variable isotopic signatures and turnover (Ehleringer et al., 2000). The soil $\delta^{13} \mathrm{C}$ values (-8.3\%o to $-6.7 \%$ ) were higher than those for roots $(-20.2 \%$ to $-15.6 \%$ ) and aboveground plant tissue ( $-27.9 \%$ to $-13.3 \%$ ). The greater $\delta^{13} \mathrm{C}$ values for soil compared to plants is consistent with isotopic fractionation during decomposition, whereby ${ }^{12} \mathrm{C}$ is preferentially lost as $\mathrm{CO}_{2}$, while ${ }^{13} \mathrm{C}$ is retained and stabilized in the soil (Han et al., 2008). The ranges, from $-27.9 \%$ to $-25.1 \%$ for ${ }^{13} \mathrm{C}$ values of 11 species and from $-13.3 \%$ to $-14.3 \%$ for two species, were typical in plants using the $\mathrm{C}_{3}$ and $\mathrm{C}_{4}$ photosynthetic pathways, similar to those values reported by Derner et al. (2006) and Deines (1980) for $C_{3}$ and $C_{4}$ plant species. The $\delta^{13} \mathrm{C}$ values in the aboveground plant tissue were uniform between grazed and ungrazed desert grassland. Grazing decreased the $\delta^{13} \mathrm{C}$ values of legume and grass species. The slightly greater ${ }^{13} \mathrm{C}$ values with ungrazed compared to grazed grasslands are consistent with greater discrimination against ${ }^{13} \mathrm{C}$ in the atmospheric $\mathrm{CO}_{2}$ under better moisture conditions than that is expected in ungrazed grassland. Better moisture conditions favor more open stomata and the preferential uptake of ${ }^{12} \mathrm{C}$ over ${ }^{13} \mathrm{C}$. The $\delta^{13} \mathrm{C}$ values decreased, pointing to limitations in photosynthesis, which may have reduced the capacity for $\mathrm{N}$ assimilation.

\section{Conclusions}

This study presents the evidence, i.e. the differences in grazing can cause far-reaching changes in SOC, as indicated by the SOC and total $\mathrm{N}$ contents. The SOC and total $\mathrm{N}$ contents decreased with grazing in semiarid desert grassland. Significant decreases in the SOC and total $\mathrm{N}$ contents may be attributed to the decrease in plant aboveground vegetation and changes in soil properties under grazing. Grazing did not lead to significant variation in the $\delta^{15} \mathrm{~N}$ of the soil, but resulted in a significant increase in the $\delta^{13} \mathrm{C}$ of soil. Grazing effects on the $\delta^{15} \mathrm{~N}$ and the $\delta^{13} \mathrm{C}$ values of plants were uniform among species, and the $\delta^{15} \mathrm{~N}$ values of five species decreased with grazing. Our findings suggest that changes in biomass, vegetation coverage characteristics, SOC and total $\mathrm{N}$ contents were good indica- tors to grazing pressure on grassland ecosystems. The SOC and the total $\mathrm{N}$ were sensitive to grazing and difficult to recover after a significant decline has been caused by grazing in desert grassland.

\section{Acknowledgments}

The research was financially supported by the National Natural Science Foundation of China $(31260125,31000214)$. The authors would also thank the anonymous reviewers for their helpful comments, which resulted in a significant improvement of the manuscript.

\section{References}

Baron V S, Mapfumo E, Dick A C, et al. 2002. Grazing intensity impacts on pasture carbon and nitrogen flow. Journal of Range Management, 55: 535-541.

Cheng J, Wu G, Zhao L, et al. 2011. Cumulative effects of 20-year exclusion of livestock grazing on above- and belowground biomass of typical steppe communities in arid areas of the Loess Plateau, China. Plant, Soil and Environment, 57: 40-44.

Cheng W X, Chen Q S, Xu Y Q, et al. 2009. Climate and ecosystem ${ }^{15} \mathrm{~N}$ natural abundance along a transect of Inner Mongolian grasslands: Contrasting regional patterns and global patterns. Global Biogeochemical Cycles, 23: GB2005.

Conant R T, Paustian K, Elliott E T. 2001. Grassland management and conversion into grassland: effects on soil carbon. Ecological Applications, 11: 343-355.

Cui X Y, Wang Y F, Niu H S, et al. 2005. Effect of long-term grazing on soil organic carbon content in semiarid steppes in Inner Mongolia. Ecological Research, 20: 519-527.

Deines P. 1980. The isotopic composition of reduced organic carbon. In: Fritz P, Fontes J C. Handbook of Environmental Isotope Geochemistry I, the Terrestrial Environment. Amsterdam: Elsevier, 329-345.

Derner J D, Boutton T W, Briske D D. 2006. Grazing and ecosystem carbon storage in the North American Great Plains. Plant and Soil, 280: 77-90.

Dixon E R, Blackwell M S A, Dhanoa M S, et al. 2010. Measurement at the field scale of soil $\delta^{13} \mathrm{C}$ and $\delta^{15} \mathrm{~N}$ under improved grassland. Rapid Communications in Mass Spectrometry, 24: 511-518.

Ehleringer J R, Buchmann N, Flanagan L B. 2000. Carbon isotope ratios in belowground carbon cycle processes. Ecological Applications, 10: $412-422$.

Evans R D, Ehleringer J R. 1994. Water and nitrogen dynamics in an arid woodland. Oecologia, 99: 233-242.

Evans R D, Bloom A J, Sukrapanna S S, et al. 1996. Nitrogen isotope composition of tomato (Lycopersicon esculentum Mill. cv. T-5) grown under ammonium or nitrate nutrition. Plant, Cell and Environment, 19: 1317-1323.

Feigin A, Kohl D H, Shearer G, et al. 1974. Variation in the natural nitrogen-15 abundance in nitrate mineralized during incubation of several Illinois soils. Soil Science Society of America Journal, 38: 90-95. 
Frank D A, Evans R D. 1997. Effects of native grazers on grassland N cycling in Yellowstone National Park. Ecology, 78: 2238-2248.

Frank D A, Groffman P M, Evans R D, et al. 2000. Ungulate stimulation of nitrogen cycling and retention in Yellowstone Park grasslands. Oecologia, 123: 116-121.

Frank D A, Evans R D, Tracy B F. 2004. The role of ammonia volatilization in controlling the natural ${ }^{15} \mathrm{~N}$ abundance of a grazed grassland. Biogeochemistry, 68: 169-178.

Gao Y H, Luo P, Wu N, et al. 2007. Biomass and nitrogen responses to grazing intensity in an alpine meadow on the eastern Tibetan Plateau. Polish Journal of Ecology, 55: 469-479.

Gillson L, Hoffman M T. 2007. Rangeland ecology in a changing world. Science, 315: 53-54.

Golluscio R A, Austin A T, García M G C, et al. 2009. Sheep grazing decreases organic carbon and nitrogen pools in the Patagonian Steppe: combination of direct and indirect effects. Ecosystems, 12: 686-697.

Han G D, Hao X Y, Zhao M L, et al. 2008. Effect of grazing intensity on carbon and nitrogen in soil and vegetation in a meadow steppe in Inner Mongolia. Agriculture, Ecosystems \& Environment, 125: 21-32.

Harris W N, Moretto A S, Distel R A, et al. 2007. Fire and grazing in grasslands of the Argentine Caldenal: effects on plant and soil carbon and nitrogen. Acta Oecologica, 32: 207-214.

Högberg P, Högbom L, Schinkel H, et al. 1996. 15N abundance of surface soils, roots and mycorrhizas in profiles of European forest soils. Oecologia, 108: 207-214.

Holland E A, Detling J K. 1990. Plant response to herbivory and belowground nitrogen cycling. Ecology, 71: 1040-1049.

Kang L, Han X, Zhang Z, et al. 2007. Grassland ecosystems in China: review of current knowledge and research advancement. Philosophical Transactions of the Royal Society B: Biological Sciences, 362: 997-1008.

Ma H B, Xie Y Z. 2008. Plant compensatory growth under different grazing intensities in desert steppe. Scientia Agricultura Sinica, 41: 3645-3650. (in Chinese)

Milchunas D G, Lauenroth W K. 1993. Quantitative effects of grazing on vegetation and soils over a global range of environments. Ecological Monographs, 63: 327-366.

Nadelhoffer K J, Fry B. 1994. Nitrogen isotope studies in forest ecosystems. In: Michener R, Lajtha K. Stable Isotopes in Ecology and Environmental Science. Oxford: Blackwell Scientific, 22-44.

Natelhoffer K, Fry B. 1988. Controls on natural nitrogen-15 and carbon-13 abundances in forest soil organic matter. Soil Science Society of America Journal, 52: 1633-1640.

Neff J C, Reynolds R L, Belnap J, et al. 2005. Multi-decadal impacts of grazing on soil physical and biogeochemical properties in southeast Utah. Ecological Applications, 15: 87-95.
Olofsson J, Kitti H, Rautiainen P, et al. 2001. Effects of summer grazing by reindeer on composition of vegetation, productivity and nitrogen cycling. Ecography, 24: 13-24.

Piñeiro G, Paruelo J M, Oesterheld M. 2006. Potential long-term impacts of livestock introduction on carbon and nitrogen cycling in grasslands of Southern South America. Global Change Biology, 12: 1267-1284.

Rossignol N, Bonis A, Bouzillé J B. 2006. Consequence of grazing pattern and vegetation structure on the spatial variations of net $\mathrm{N}$ mineralisation in a wet grassland. Applied Soil Ecology, 31: 62-72.

Savadogo P, Sawadogo L, Tiveau D. 2007. Effects of grazing intensity and prescribed fire on soil physical and hydrological properties and pasture yield in the savanna woodlands of Burkina Faso. Agriculture, Ecosystems \& Environment, 118: 80-92.

Schlesinger W H. 1997. Biogeochemistry: an Analysis of Global Change. New York: Academic Press.

Scurlock J M O, Hall D O. 1998. The global carbon sink: a grassland perspective. Global Change Biology, 4: 229-233.

Stark S, Grellmann D. 2002. Soil microbial responses to herbivory in an arctic tundra heath at two levels of nutrient availability. Ecology, 83: 2736-2744.

Su Y Z, Li Y L, Cui J Y, et al. 2005. Influences of continuous grazing and livestock exclusion on soil properties in a degraded sandy grassland, Inner Mongolia, northern China. Catena, 59: 267-278.

Templer P H, Arthur M A, Lovett G M, et al. 2007. Plant and soil natural abundance $\delta^{15} \mathrm{~N}$ : indicators of relative rates of nitrogen cycling in temperate forest ecosystems. Oecologia, 153: 399-406.

Tracy B F, Frank D A. 1998. Herbivore influence on soil microbial biomass and nitrogen mineralization in a northern grassland ecosystem: Yellowstone National Park. Oecologia, 114: 556-562.

Van Wijnen H J, Van Der Wal R, Bakker J P. 1999. The impact of herbivores on nitrogen mineralization rate: consequences for salt-marsh succession. Oecologia, 118: 225-231.

Wu G L, Liu Z H, Zhang L, et al. 2010. Long-term fencing improved soil properties and soil organic carbon storage in an alpine swamp meadow of western China. Plant and Soil, 332: 331-337.

Zacheis A, Ruess R W, Hupp J W. 2002. Nitrogen dynamics in an Alaskan salt marsh following spring use by geese. Oecologia, 130: 600-608.

Zhang K B, Li R, Hou R P, et al. 2004. Study on plant diversity of different control measures of desertification in Yanchi county, Ningxia. Science of Soil and Water Conservation, 2: 66-72. (in Chinese)

Zhou Z Y, Li F R, Chen S K, et al. 2011. Dynamics of vegetation and soil carbon and nitrogen accumulation over 26 years under controlled grazing in a desert shrubland. Plant and Soil, 341: 257-268. 